\title{
APPLICATION OF MOTIVATION-HYGIENE THEORY AMONG WORKERS OF SOCIAL CARE INSTITUTIONS
}

\author{
Rovena Kushta ${ }^{1}$
}

\begin{abstract}
Motivation of workers is a field of interest to any institution. Motivated workers displaying high levels of satisfaction, or otherwise lack of dissatisfaction, have a positive impact on the overall work performance. The study aims to measure motivation levels and the influence of factors such as motivation-hygiene on satisfaction/dissatisfaction level among workers of social care institutions. A quantitative method of assessment is used. The sample consists of 110 workers. Results show a positive and statistically significant correlation between motivation factors and the levels of satisfaction with work. Responsibility is the selected factor with the biggest impact on satisfaction by the workers of the institutions surveyed. There is a positive but not statistically significant correlation between such factors as hygiene and lack of satisfaction at work. To the workers, the responsible supervisor is the factor with the biggest impact on the lack of satisfaction at work, while administrative policies are calculated as being $\mathrm{r}$ (Pearson) $=-0.27$ and sig $=0.761$, which shows that they influence the dissatisfaction levels at work. Therefore institutions must pay attention to motivation strategies with the purpose of increasing satisfaction and thus decreasing dissatisfaction levels at work.
\end{abstract}

UDC Classification: 159.9; DOI: http://dx.doi.org/10.12955/cbup.v5.1009

Keywords: motivation, workers, Herzberg's theory, Institutions of Social Care

\section{Introduction}

A series of definitions of the concepts of motivation at work have been proposed since the beginning of the $20^{\text {th }}$ century. According to Maslow (1946) "Motivation is a desire, a tendency, a drive to complete a task or a job started earlier." Vroom (1964) sees motivation as closely related to performance at work and stresses out that "the more motivated are workers in their work, the higher will their performance and results be." While Golembiewski (1973) defined motivation as "a willingness of the organization to fulfill the established goals by taking advantage of the sources at disposal."

While in the $21^{\text {st }}$ century other authors have studied motivation at work from different perspectives. Cole (2004) gives the definition as "the willingness of the individual to exert high level of effort to reach organizational goals, to satisfy some personal need." While Armstrong and Taylor (2014) put forward that "motivation is the art which helps people to focus their thoughts and energy on performing his/her tasks in the best way possible."

Several theories are observed in the field of motivation. Individuals have different needs, set goals to attain and undertake a series of actions. As a result, a single theory or strategy is not capable of satisfying everyone. Theories of motivation try to analyze and explain why workers tend to react accordingly to their efforts and personal contribution. They also describe the efficient ways how institutions/organizations can stimulate their employees toward achievement of results, and why there are not satisfying an individual's personal needs. Thus, the different theories are widely used by managers to explain the motivation of employees.

All theories can be grouped into two categories:

- Theories which try to explain motivation by focusing on content (the inside) - analyzing factors in the mind of an individual which stimulate, control, or hinder behavior and the way which individual lists them according to the degree of importance s/he places on them.

- Theories that try to explain processes explaining and analyzing the way how behavior is stimulated, controlled, or hindered; focusing on thoughts and cognitive processes which take place inside the human mind and affect behavior.

For the purpose of this study, we chose to focus on Herzberg's theory of motivation-hygiene.

Herzberg's theory has widespread due to the practical implications it has had on the motivation of workers. Herzberg (1966) concluded that the opposite of satisfaction is not dissatisfaction, unlike what was previously held. Upgrading work conditions does not necessarily result in a higher level. Based on the results of the study, the opposite of "satisfaction" is "non-satisfaction" and the opposite of

\footnotetext{
${ }^{1}$ European University of Tirana, Department of Education, Tirana, Albania, rovena.lika@uet.edu.al
} 
"dissatisfaction" is "non-dissatisfaction", while the factors contributing to satisfaction are separate and different from the ones which lead to dissatisfaction.

Factors that bring about satisfaction are the above mentioned inner factors, which Herzberg (1966) termed as motivating factors, while the factors that lead to dissatisfaction are outside factors for which he used the term hygiene factors.

More concretely, a state of dissatisfaction may be caused by the company's policies, supervision, interpersonal relations, and salary or work conditions. When these do not meet a satisfactory level, workers tend to feel dissatisfied. On the other hand, when these factors measure to a sufficient level, workers are simply not dissatisfied. Satisfaction means achievement, gratefulness, work itself, responsibility, promotion, and these are the factors which account for motivation, while the absence of the abovementioned does not result in any particular dissatisfaction.

\section{Methodology}

The object of this study is to measure the level of motivation and the impact that factors motivationhygiene, have on satisfaction/dissatisfaction levels among workers of Social Care Institutions in Tirana. Hypotheses of this study are:

1. A positive relationship exists between motivating factors and satisfaction at work.

2. A positive relationship exists between hygiene factors and lack of satisfaction at work.

\section{Measurement instrument}

The study uses a quantitative method, which consists of a questionnaire as an instrument to measure the level of motivation and the impact of factors motivation-hygiene on satisfaction/dissatisfaction among workers of social care institutions. The questionnaire consists of 48 questions in total.

Subjects were asked questions to gather demographic data such as: gender, age, education, job position in the institution they work and the period of time they have been occupying the position.

The second part consists of 31 questions regarding the level of satisfaction and dissatisfaction. Subjects were asked if they feel satisfied with their work; if they are familiar and agree with the institution's policy; if they get along with the other work mates; if they find their salary decent; how do they perceive supervision at work; if they find their work environment acceptable, etc.

The third section asks respondents 12 questions on factors that are sources of motivation or not at work.Subjects were asked how motivating factors (achievement; promotion; work itself; recognition; responsibility and advancement) and hygiene factors (administrative policies; responsible supervisor; work conditions; salary; interpersonal relations and status) influence the motivation of employees at work.

\section{Results}

Most subjects were females (91\%), aged over 48 years (40\%), having high school education (49\%). Most respondents occupied the position of caregiver and working period in that position stretching over $1-5$ years. 


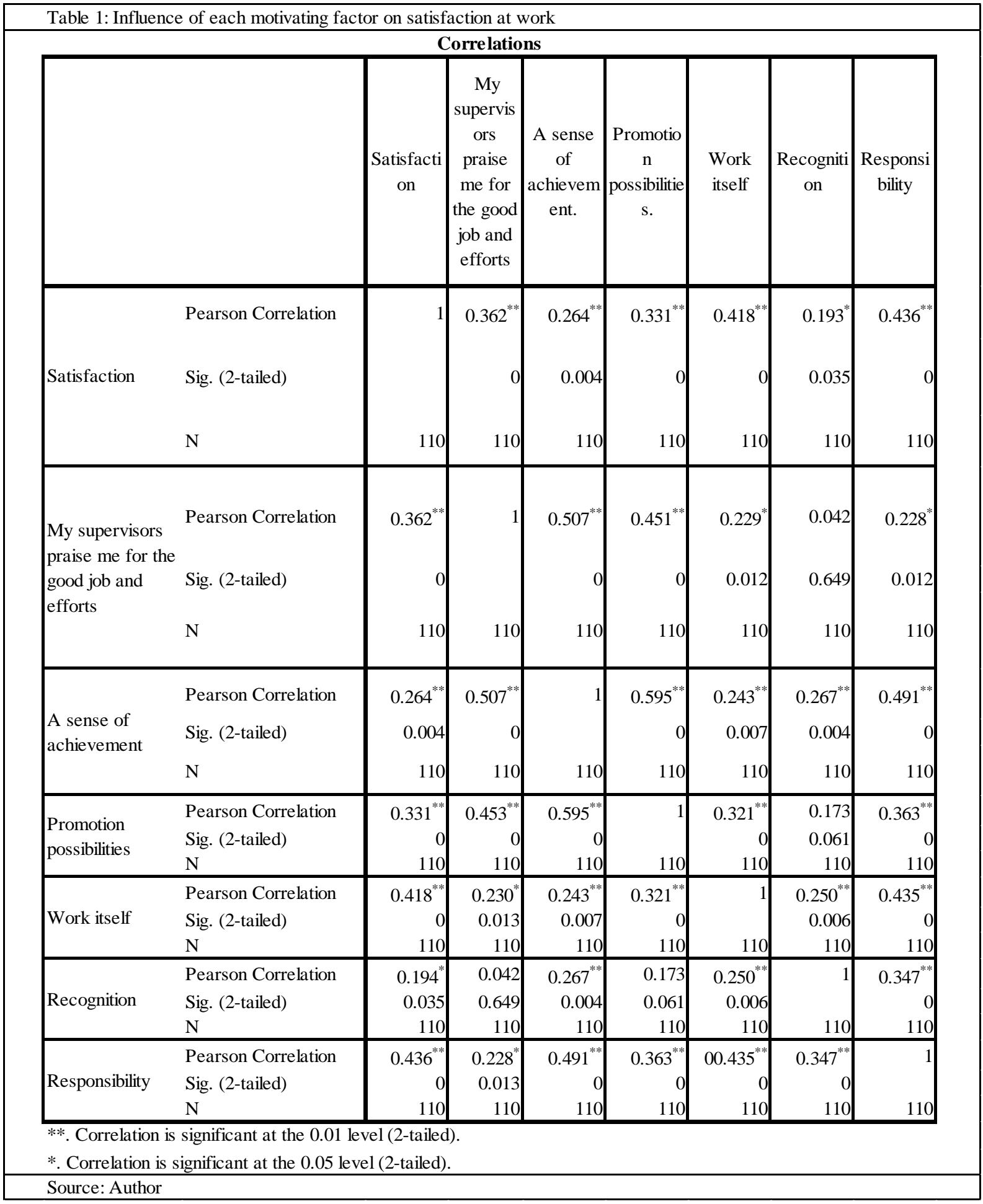

What is evident is that there is positive (indicated by Pearson's coefficient) and statistically significant ( $\mathrm{P}$-value $=$ sig being smaller than 0.05 in all cases) relationship between each factor and satisfaction at work. This can also be explained by the correlation motivation-satisfaction.

For the respondents, "responsibility" factor has the biggest impact on satisfaction (Pearson=0.436), pointing to the fact that workers prefer being responsible for the work they do and feel satisfied with this fact. "Work itself" factor follows logically (Pearson=0.418) demonstrating that workers like their job and are satisfied with it, while, "recognition" factor has the lowest impact on job satisfaction to the surveyed subjects (Pearson=0.194). 
Table 2: Influence of each hygiene factor on lack of satisfaction at work:

\begin{tabular}{|c|c|c|c|c|c|c|c|c|}
\hline & & $\begin{array}{c}\text { Lack of } \\
\text { satisfactio } \\
\mathrm{n} \\
\end{array}$ & Salary & $\begin{array}{c}\text { Interpers } \\
\text { onal } \\
\text { relations }\end{array}$ & $\begin{array}{c}\text { Responsibl } \\
\mathrm{e} \\
\text { supervisor }\end{array}$ & $\begin{array}{c}\text { Administra } \\
\text { tive } \\
\text { policies } \\
\end{array}$ & $\begin{array}{c}\text { Work } \\
\text { conditions }\end{array}$ & Status \\
\hline $\begin{array}{l}\text { Interpersonal } \\
\text { relations. }\end{array}$ & $\begin{array}{l}\text { Pearson Correlation } \\
\text { Sig. (2-tailed) } \\
\mathrm{N}\end{array}$ & $\begin{array}{r}0.067 \\
0.465 \\
110 \\
\end{array}$ & $\begin{array}{r}0.334^{* * *} \\
0 \\
110 \\
\end{array}$ & $\begin{array}{r}1 \\
110 \\
\end{array}$ & $\begin{array}{r}0.374^{* * *} \\
0 \\
110 \\
\end{array}$ & $\begin{array}{r}0.359^{* * *} \\
0 \\
110 \\
\end{array}$ & $\begin{array}{r}0.197^{*} \\
0.032 \\
110 \\
\end{array}$ & $\begin{array}{r}0.313^{* * *} \\
0.001 \\
110 \\
\end{array}$ \\
\hline $\begin{array}{l}\text { Administrative } \\
\text { policies }\end{array}$ & $\begin{array}{l}\text { Pearson Correlation } \\
\text { Sig. (2-tailed) } \\
\mathrm{N}\end{array}$ & $\begin{array}{r}-0.027 \\
0.761 \\
110 \\
\end{array}$ & $\begin{array}{r}0.311^{* *} \\
0.001 \\
110 \\
\end{array}$ & $\begin{array}{r}0.359^{* * *} \\
0 \\
110 \\
\end{array}$ & $\begin{array}{r}0.626^{* * *} \\
0 \\
110\end{array}$ & $\begin{array}{r}1 \\
110 \\
\end{array}$ & $\begin{array}{r}0.211^{*} \\
0.021 \\
110\end{array}$ & $\begin{array}{r}0.233^{*} \\
0.011 \\
110 \\
\end{array}$ \\
\hline $\begin{array}{l}\text { Work } \\
\text { conditions }\end{array}$ & $\begin{array}{l}\text { Pearson Correlation } \\
\text { Sig. (2-tailed) } \\
\mathrm{N}\end{array}$ & $\begin{array}{r}0.069 \\
0.452 \\
110 \\
\end{array}$ & $\begin{array}{r}0.208^{*} \\
0.024 \\
110 \\
\end{array}$ & $\begin{array}{r}0.197^{*} \\
0.032 \\
110 \\
\end{array}$ & $\begin{array}{r}0.126 \\
0.174 \\
110 \\
\end{array}$ & $\begin{array}{r}0.211^{*} \\
0.021 \\
110 \\
\end{array}$ & $\begin{array}{r}1 \\
110 \\
\end{array}$ & $\begin{array}{r}0.14 \\
0.129 \\
110 \\
\end{array}$ \\
\hline Status & $\begin{array}{l}\text { Pearson Correlation } \\
\text { Sig. (2-tailed) } \\
\text { N }\end{array}$ & $\begin{array}{r}0.052 \\
0.571 \\
110\end{array}$ & $\begin{array}{r}0.356^{* * *} \\
0 \\
110\end{array}$ & $\begin{array}{r}0.313^{\text {*** }} \\
0.001 \\
110\end{array}$ & $\begin{array}{r}0.158 \\
0.086 \\
110\end{array}$ & $\begin{array}{r}0.233^{*} \\
0.011 \\
110\end{array}$ & $\begin{array}{r}0.14 \\
0.129 \\
110\end{array}$ & $\begin{array}{r}1 \\
110\end{array}$ \\
\hline
\end{tabular}

As it can be viewed from the table not every relationship between hygiene and lack of satisfaction factors is equally important from the statistic point of view. It is clear that the "responsible supervisor" factor (Pearson=0.327 and sig=0.000) has the biggest impact on the lack of satisfaction. Workers value supervisors for the task they perform and consider them as a factor contributing to dissatisfaction. On the other hand, the other factors do not show a statistically significant relation which means that they are not responsible for lack of satisfaction. "Administrative policies" show even a negative relationship with lack of satisfaction.

\section{Correlation between motivating factors and satisfaction at work}

\begin{tabular}{l} 
Table 3: Correlations \\
$\qquad$\begin{tabular}{|ll|r|r|}
\hline & \multicolumn{1}{|c|}{ Motivation } & Satisfaction \\
\hline Motivation & Pearson Correlation & $0.484^{* *}$ \\
& Sig. (2-tailed) & & 0.000 \\
& $\mathrm{~N}$ & 110 & 110 \\
\hline Satisfaction & Pearson Correlation & $0.484^{* *}$ & 1 \\
& Sig. (2-tailed) & 0.000 & 110 \\
\hline & $\mathrm{N}$ & 110 & \\
\hline
\end{tabular} \\
\hline
\end{tabular}

Based on the data from the above table a positive relation exists between motivating factors and satisfaction at work, where $\mathrm{r}=0.484$ and $\mathrm{P}$-values $=\mathrm{sig}=0.000$. Therefore to workers of Social Care Institutions in Tirana, motivating factors (achievement, promotion, recognition, work itself, advancement, and responsibility) influence satisfaction at work, which confirms Herzberg's theory. 


\section{Correlation between hygiene and lack of satisfaction at work}

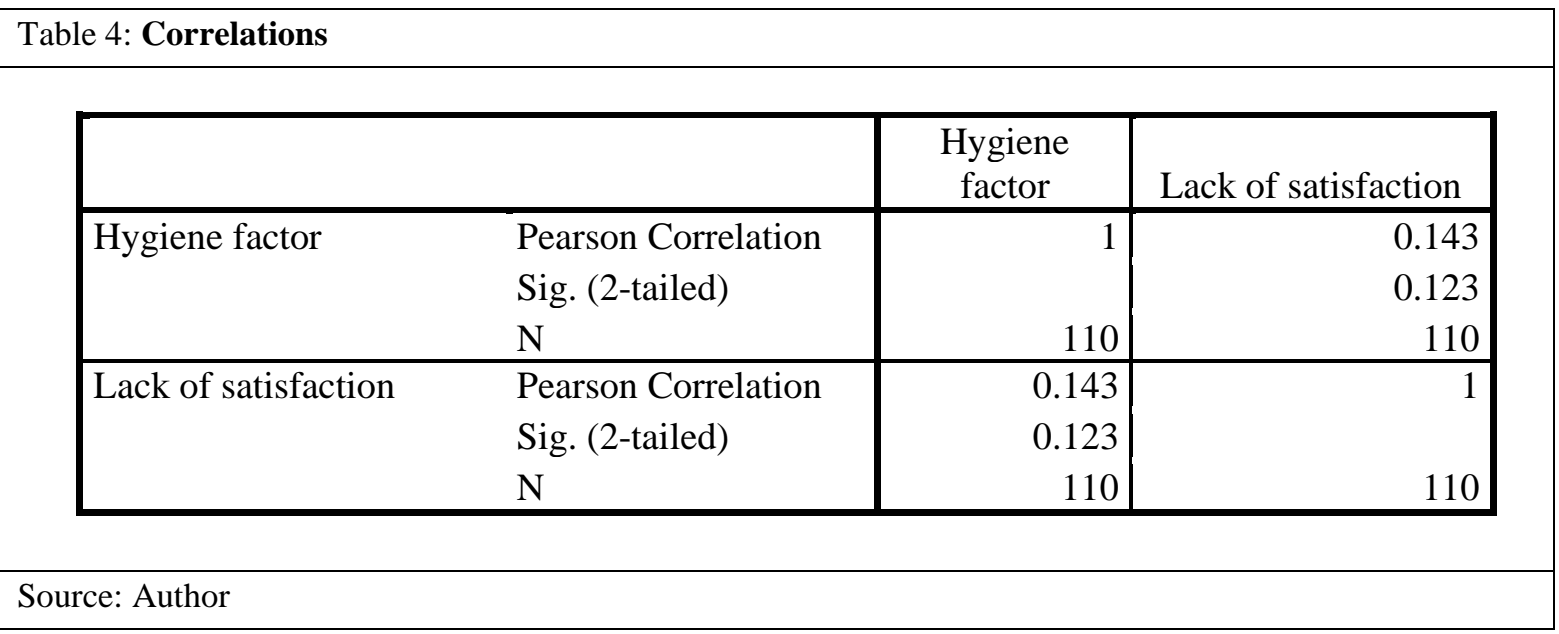

Through the data obtained from this study we conclude that, "the relation between hygiene factors and lack of satisfaction is positive, but not one which is statistically significant". This means that the phenomenon is not true in all cases, or in other words hygiene factors do not always influence on the lack of satisfaction.

To the respondents (workers of social care institutions) hygiene factors (institution's policies, supervisor, interpersonal relations, salary, work conditions, status) do not always bring lack of satisfaction.

\section{Conclusions}

This study, targeting workers of social care institutions in Tirana, aimed to measure motivation levels and the impact of factors motivation-hygiene on the level of satisfaction/dissatisfaction at work experienced by the workers of the surveyed institutions. After analyzing the quantitative data collected through the questionnaire carried out among 110 workers, we conclude as follows:

The staff of social care institutions consists mainly of females, which points to the fact that caregiving is viewed as a gender role associated with women, but also because caregiving is often the job preferred by many of this gender category.

Motivation factors show a positive relationship with satisfaction at work, and among the factors, responsibility was the one ranking highest in terms of impact on satisfaction levels for the workers of social care institutions.

Workers of social care institutions consider work in itself a source of motivation for performing their tasks, which is observed by the positive relationship between this factor and satisfaction at work.

Praising workers for their effort and professional advancement was seen as a source of encouragement and enthusiasm at work by the respondents, which is confirmed by the positive and statistically significant relationship between this factor and satisfaction at work.

Workers of social care institutions result to feel satisfied with their job, which can be seen in their answers to the question if they would prefer to work somewhere else not in the field of social care.

Social care institutions encourage promotion opportunities, and to the workers of these institutions this is seen as a motivating factor that leads to satisfaction at work.

Social care institutions acknowledge cases when their workers do unpaid work, which results in being a factor that increases enthusiasm and encourages workers, therefore having an impact on satisfaction.

Responsible supervisors are deemed by workers as the factor having the biggest impact on lack of satisfaction, indicating that they agreed with supervising practices at their workplace and found their supervisors supportive rather than reproaching.

Workers admitted having friendly relations with co-workers, which according to Herzberg's theory is viewed as a factor influencing lack of satisfaction.

Workers spoke highly of their work environment, which proves that work conditions are a factor which leads to the reduction of dissatisfaction among workers of social care institutions. 
Salary and status are factors which increase enthusiasm and encouragement at work, and in the case of workers of social care institutions correlations show that there is a positive relationship between factors and lack of satisfaction, but not statistically important, which means that when the factors are of a low level they do not always result in lack of satisfaction.

Administrative policies show a negative but not strong relation with the lack of satisfaction at work, which according to Herzberg means a hygiene factor resulting in dissatisfaction.

Recommendations

Some recommendations that can improve the situation are listed as follows:

Importance should be given to the work performed by the employees as referring to the wage system, and rewarding financial stimuli should be applied in order to increase satisfaction at work.

More frequent seminars and training sessions should be organized by the institutions or higher hierarchic structures, thus encouraging participation and inclusion of workers as a valuable asset.

Qualification of workers, particularly of those having direct contact with the target, should be of a university level conveying the necessary professional competence for a more efficient performance at work.

Supervising practice to acquire a supportive role for workers due to its impact on satisfaction at work.

Institutions to provide agreeable work facilities to serve performance, the accomplishment of objectives and increase of satisfaction levels.

Collaborative interpersonal relations should be fostered by eliminating hierarchical barriers which result in reduced levels of dissatisfaction among workers.

\section{References}

Armstrong M., Taylor, S. (2014) Armstrong's Handbook of Human Resource Management Practice. (13 ${ }^{\text {th }}$ Edition) Ashford Colour press Ltd. Retrieved from:

https://otgo.tehran.ir/Portals/0/pdf/Armstrong's\%20Handbook\%20of\%20Human\%20Resource\%20Management\%20Practice_ 1.pdf

Cole, G. A. (2004). Management theory and practice ( $6^{\text {th }}$ edition) Thomson Learning, London

Golembiewski, R. T. (1973). Motivation in Carl Hayel, The Encyclopedia of Managment 2nd. New York: Van Nostrand Reinhold

Herzberg, F. (1966). Work and the nature of man. Cleveland: World Publishing Company. Retrieved from https://www.joe.org/joe/1967summer/1967-2-brv1.pdf

Maslow, A. (1946). A theory of human motivation. Psychological Review, 50, 370-396.

Vroom, V. H. (1964). Work and motivation, New York: John Wiley. 